\title{
Web-Based Partograph on Early Detection of Emergency Cases and Referral Processes
}

\author{
Devianti Tandiallo ${ }^{1}$, Mardiana Ahmad ${ }^{1}$, Syafruddin Syarif ${ }^{1,2}$, Nasrudin A. Mappaware ${ }^{1,3}$, \\ Prihantono $^{1,4}$ \& Burhanuddin Bahar ${ }^{1,5}$ \\ ${ }^{1}$ Postgraduate Program, Depertment of Midwifery, Hasanuddin University, Makassar, South Sulawesi, Indonesia \\ ${ }^{2}$ Depertment of Electrical Engineering, Hasanuddin University, Makassar, South Sulawesi, Indonesia \\ ${ }^{3}$ Medical Faculty, Universitas Muslim Indonesia, Makassar, South Sulawesi, Indonesia \\ ${ }^{4}$ Depertment of Surgery, Faculty of Medicine, Hasanuddin University, Makassar, South Sulawesi, Indonesia \\ ${ }^{5}$ Faculty of Public Health, Depertment of Nutrition, Hasanuddin University, Makassar, South Sulawesi, Indonesia \\ Correspondence: Devianti Tandiallo, Postgraduate Program, Department of Midwifery, Hasanuddin University, \\ Makassar, South Sulawesi, 90245, Indonesia. Tel: 62-822-9853-5091. E-mail: deviantit@gmail.com
}

Received: March 24, 2019 Accepted: April 22, 2019 Online Published: May 3, 2019

doi:10.5539/gjhs.v11n6p79 URL: https://doi.org/10.5539/gjhs.v11n6p79

\begin{abstract}
Introduction: The partograph is designed as a tool to monitor a woman's progress of labor. If it is used appropriately, the partograph can be used as a means of prevention and an early warning system to the need for further action such as caesarian section. The used of partograph is able to lower the percentage of Maternal Mortality Rate (MMR) and Infant Mortality Rate (IMR). This study aimed to determine the comparison between word electric browser (WEB)-based partograph and the conventional partograph.

Materials and Methods: This study aimed to compare between the use of WEB-based patorgaph and conventional patograph. To gain the data, the researcher adopted quasi experimental method. Using purposive sampling technique, 30 women in labour were participated in this study. The data were analyzed by using the Independent T- test and Mann-Whitney test.

Results: The result of the study showed that the utilization of WEB-based partograph is faster in recording the contraction, oxytocin, and the process of giving birth than the utilization of conventional partograph. Furtehrmore, promptness of WEB-based partograph in early detection has p-value $0.000(<0.05)$ and p-value in emergency detection is $0.014(<0.05)$ which means that there was differences between the use of WEB-based partograph and conventional partograph. Meanwhile, p-value of referral process is $1.000(>0.05)$ which means that there was no difference in using both WEB-based partograph and conventional partograph.
\end{abstract}

Conclusion: This means that using the monitoring of the WEB-based partograph or the conventional partograph showed differences. The utilization of WEB-based partograph is better than conventional partograph since it can be used as a means to monitor the progress of labour.

Keywords: WEB-based partograph, conventional partograph, emergency cases, referral process

\section{Introduction}

The partograph is a means to monitor the labor progress. Moreover, it can be used as a means of prevention and an early warning system to the need for further action such as cesarean section, if it is used appropriately. The partograph is used by women in labor during the first active phase. It is used to monitor the progress of labor and its complication such as obstructed and prolonged labor which can threaten the mother and the baby. Thus, the use of partograph can reduce the maternal mortality rate (MMR) and infant mortality rate (IMR) (Yisma, Dessalegn, Astatkie, \& Fesseha,, 2013b; Bedwell, Levin, Pett, \& Lavender, 2017; Mezmur, Semahegn, \& Tegegne, 2017; Mathibe Neke \& Matupa, 2013; Wakgari, Tessema, \& Amano, 2015; Mandiwa \& Zamawe, 2017; Florence, Beverley, Gyekye, \& Schopflocher, 2013; Dalal \& Purandare, 2018; Konlan, Kombat, Wuffele, \& Aarah-Bapuah, 2016).

The partograph was first discussed by Friedman in 1950s, and then it was developed and designed by Philpott in Harare in 1971 using the concept of warning signs and action line. In 1973, partograph became a tool to 
differentiate between normal and abnormal labor. Moreover, World Health Organization (WHO) launched partograph which is used to monitoring cervical dilatation, fetal head loss, uterine contractions, and fetal heart rate (Yisma, Dessalegn, Astatkie, \& Fesseha, 2013a; Mathibe Neke \& Matupa, 2013; Asibong et al., 2014; Ollerhead \& Osrin, 2014).

The use of partograph such as in emergency cases can be used as a tool to monitor the progress of labor. Scholars found that $41,1 \%$ of maternal and fetal did not get the treatment to record their fetal heart rate, $41,4 \%$ cervical dilatation, and $45 \%$ uterine contraction. Emergency case during labor process is a condition which can cause the pain and even death to both a mother and a baby. In this case, the umbilical cord winding causes the fetus to experience hypoxemia which resulting in fetal distress. Furthermore, fetal distress can inhibit the decline of fetal presentation to the lowest part of the fetus so that the risk of cesarean section is carried out (Yisma et al., 2013b, Kuppens, Smailbegovic, Houterman, De Leeuw, \& Hasaart, 2017; Wang, Kuromaki, Ochi, Kikugawa, Matsunaga, \& Takagi, 2016; De Plecker et al., 2017; Markos \& Bogale, 2016; Dalal \& Purandare, 2018).

WHO in 2003 reported that an estimation of the maternal mortality rate is around 289,000 . This case was caused by postpartum hemorrhage (64\%), hypertension $(15,62 \%)$, and pulmonary embolism $(6,25 \%)$. Most of the Mother Were found death due to delay in getting well treatment $(56,25 \%)$ and delay in getting the appropriate health facilities $(33,3 \%)$. These were happened because the inability of the health staffs to detect early obstetric emergency and their inability to process the referral for further action (Kumar \& Agrawal, 2016; Assarag, Dujardin, Delamou, Still, \& De Brouwere, 2015).

Based on Indonesian health demographic survey (IDHS) in 2012, the rate of maternal mortality in Indonesia increased at 359 deaths per 100.000 live births comparing in 2007 at the level 228 deaths per 100.000 live births. The death was caused by bleeding, hypertension, and prolonged labor. Meanwhile, the rate of infant mortality in 2012 is around 32 deaths per 1.000 live births (Profile of Ministry of health, 2015).

The study conducted by Lubuk Buaya Padang reported that $54,8 \%$ of independent midwifery practice recorded the partograph completely meanwhile $45,2 \%$ of them recorded the partograph incompletely. Furthermore, $74,2 \%$ of midwives know how to use partograph properly, in contrast $25,8 \%$ of midwives did not know how to use partograph properly. The result of the study proves the low frequency of midwives in recording partograph properly and completely. The women in labor in Tanjung Pinang who are not monitored by partograph have a tendency around $2,62 \%$ in getting ceaser section rather than the one who are monitored by partograph. Thus, the utilization of partograph is essential in monitoring the labor process. However, scholars have found that recording partograph never be attached in the process of referral to a private hospital because it was used to the disbursement of Jamkesmas's (healt insurance) funds. Whereas, if the partograph is used appropriately, it could reduce the maternal mortality rate (MMR) and infant mortality rate (IMR). It is based on the researchers who found that 293 (72,7\%) people agree on this statement (Yusuf, 2016; Pusparinda, 2015; Wakgari et al., 2015; Mandiwa \& Zamawe, 2017; Widyana, 2011).

Early detection of obstetric emergencies still needs to be improved. It is due to the decision making by families and health employees which affects to the morbidity and mortality of maternal and fetal. The death factor of maternal is the retardation in getting a well treatment. Thus, it needs partograph to monitor the maternal condition, particularly the latest one namely, computer-based partograph. Related with the previous studies, computer-based partograph has a speed to record about 8.6 hours compared to conventional partograph which takes 11.6 hours to record. Partograph is also developed in World Wide Web - based. This kind of partograph can work on computer and internet network, thus it can cut the 3T (being late in decision making, being late in processing the referral, and being late in receiving a treatment), if WEB-based partograph is used appropriately. The WEB-based partograph can be used as a tool for early detection of possible occurrence of complication in labor process, emergency cases, and in processing the early referrals (Pusparinda, 2015; Archa \& Prem, 2013; Trisna, Syarif, Ahmad, Manyu, \& Isharya, 2018; Nakimuli et al., 2016; Delimayanti, 2007; Chaturvedi et al., 2015).

\section{Materials and Methods}

\subsection{Design of the Study and Sample Population}

The method in this study is quasi-experimental by giving a treatment to the respondent during data collection and monitoring mothers in labor using a partograph convensional and web-based partograph. Two communities of health center which located in Antang Perumnas and Bara-Baraya, Makassar city, South Sulawesi province were chosen as places to conduct the study. The study was conducted from November, 2018 to Januari, 2019. The researcher used convensional partograph, web-based partograph, Computer as well as software, Wifi, stopwatch, manual book (procedure), a sheet of observation or documentation. 
The population in this study was all of women in labor who fulfilled the study requirements. The samples in this study were women who give birth normally as well as labor delivery emergencies. The sampling technique used by the researcher was purposive sampling technique. All of subjects which require the inclusion and exclusion criteria in this study were chosen. The required sample was based on Wilcoxon signed table, which is a minimum sample of 5 samples in each group. The number of samples taken was 30 mothers in labor, with conventional partograph-based use and use of Web-based partograph according to the criteria expected by the researcher.

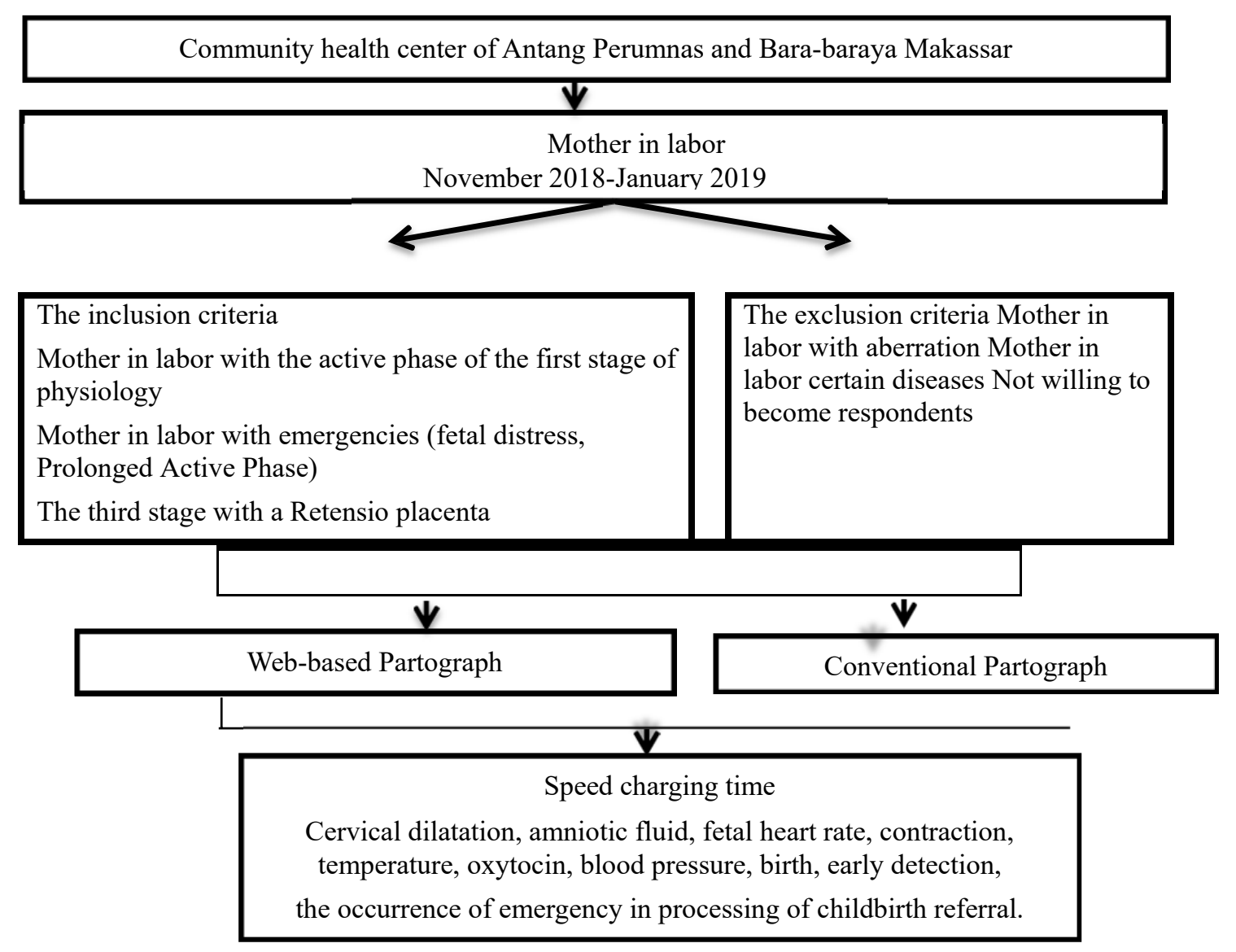

Figure 1. The flowchart of the Study

\subsection{Data Collection}

Mothers were checked up by the midwife. It was also monitored by using web-based partograph and conventionalbased partograph which was measured by using documentation and stopwatch during partograph recording.

\subsection{Ethical Considerations}

The study received ethical clearance from the Research and Ethics Committee of the Medical Faculty of Hasanuddin University and was registered 1018/H4.8.4.5.31/PP36-KOMETIK/2018.

\subsection{Data Management and Analysis}

Descriptive analysis was presented as a frequency. T-test was used to assessing the speed of partograph filling and Mann-Whitney Test was used to assessing the punctuality in detecting emergency cases as well as the refferral process. The data were analyzed by statistical package for social sciences (SPSS) version 22 for windows.

\section{Results}

\subsection{Characteristics of Respondents}

Characteristics of respondents were used to determine the diversity of respondents based on age. These characteristics were expected to provide an overview of the condition of the respondent. 
Table 1. Age of respondents in community health center of Antang Perumnas and Bara-Baraya, 2018

\begin{tabular}{lll}
\hline Patient age & Frequency & Percent \% \\
\hline$<20$ & 4 & 13.3 \\
$20-35$ & 21 & 70.0 \\
$>35$ & 5 & 16.7 \\
\hline Total & 30 & 100.0 \\
\hline
\end{tabular}

Source: Primary Data.

Table 2. Characteristict Parity

\begin{tabular}{lll}
\hline Variabel & Frequency & Percent \% \\
\hline Primigravida & 8 & 26.7 \\
Multigravida & 21 & 70.0 \\
Grandemultigravida & 1 & 3.3 \\
\hline Total & 30 & 100 \\
\hline
\end{tabular}

Source: Primary Data.

\subsection{Analysis Bivariat}

30 participants in this study were monitored by using web-based partograph and conventional partograph. As shown in Table 3, it was found that recording contractions, oxytocin and newborns were faster in using web-based partograph than using conventional partograph. In contrast, conventional partograph were faster in recording cervical dilatation, fetal heart rate, temperature, blood pressure.

Table 3. The comparison of speed monitoring betweenWEB-based partograph and conventional partograph

\begin{tabular}{|c|c|c|c|}
\hline Speed filling & (n) & Mean & Std. Deviation \\
\hline \multicolumn{4}{|l|}{ Cervical dilatation } \\
\hline \multirow[t]{2}{*}{ Web-based partograph Conventional partograph } & $(n=30)$ & 8.17 & 2.086 \\
\hline & & 4.60 & .675 \\
\hline \multicolumn{4}{|l|}{ Fetal heart rate } \\
\hline \multirow[t]{2}{*}{ Web-based partograph Conventional partograph } & $(n=30)$ & 7.47 & 1.548 \\
\hline & & 3.37 & .490 \\
\hline \multicolumn{4}{|l|}{ Fetal membrane } \\
\hline \multirow[t]{2}{*}{ Web-based partograph Conventional partograph } & $(\mathrm{n}=30)$ & 8.57 & 1.165 \\
\hline & & 5.33 & .922 \\
\hline \multicolumn{4}{|l|}{ Contraction } \\
\hline \multirow[t]{2}{*}{ Web-based partograph Conventional partograph } & $(n=30)$ & 7.97 & 1.098 \\
\hline & & 10.80 & 1.349 \\
\hline \multicolumn{4}{|l|}{ Temperature } \\
\hline \multirow[t]{2}{*}{ Web-based partograph Conventional partograph } & $(\mathrm{n}=30)$ & 8.67 & .577 \\
\hline & & 7.53 & .577 \\
\hline \multicolumn{4}{|l|}{ Oxytocin } \\
\hline \multirow[t]{2}{*}{ Web-based partograph Conventional partograph } & $(\mathrm{n}=30)$ & 7.67 & .935 \\
\hline & & 11.67 & .568 \\
\hline \multicolumn{4}{|l|}{ Blood pressure } \\
\hline \multirow[t]{2}{*}{ Web-based partograph Conventional partograph } & $(\mathrm{n}=30)$ & 8.77 & .765 \\
\hline & & 7.45 & .776 \\
\hline
\end{tabular}




\begin{tabular}{llll}
\hline Baby born & & & \\
Web-based partograph Conventional partograph & $(\mathrm{n}=30)$ & 8.67 & 1.093 \\
& & 16.53 & 1.042
\end{tabular}

Independent T-test.

Table 4. Timeliness in Detecting Early Emergency in the Delivery Referral Process

\begin{tabular}{llll}
\hline Variable & $\mathrm{n}$ & Mean Rank & $\boldsymbol{p}$-value \\
\hline Timeliness of monitoring & & & 0,000 \\
Web-based partograph Conventional partograph & $(\mathrm{n}=30)$ & 20.00 & 41.00 \\
& & & 0,014 \\
\hline Emergency Monitoring & $(\mathrm{n}=5)$ & 7.50 & 3.50 \\
Web based partograph Conventional partograph & & & 1,000 \\
\hline Referral Monitoring & $(\mathrm{n}=5)$ & 5.50 & 5.50 \\
Web-based partograph Conventional partograph & & \\
\hline
\end{tabular}

Mann-Whitney U.

\section{Discussion}

The data analysis of T-test shows that the use of web-based partograph was faster in recording contractions, Oxytocin, Babies born than conventional partograph,. In contrast, conventional partograph was faster than webbased partograph in recording Opening items, DJJ, Temperature, Blood Pressure because it only gives a cross and a dot while WEB-based partograph takes time to choose the magnitude of the cervical dilatation. The results of this study is in line with Mandiwa (2017) who found that there were still many incomplete partograph which were not recorded on partograph sheets including FHR 14\%, Molasses 25.4\%, Blood Pressure 58.6\%, Temperature 65.3\%.

Completeness of Partograph data is also Very related to health workers especially midwives. Sulistyaningsih (2007) reported that only $45 \%$ of midwives used medical records. It was also reported that out of 75 , only 1 respondent who filled it completely. The use of partograph is very important. Pusparinda (2015) stated that women in labor who are not monitored by partograph risking themselves twice in facing cesarean section. It is related with the regulation of health minister number 369/MENKES/SK/III/2007 concerning midwife professional standards who intends to monitor the progress of labor by using partograph in fostering records midwifery.

In this study, the use of conventional partographs in case of recording the cervical dilatation, fetal heart rate, molage, temperature, blood pressure were faster than WEB-based partograph. It is because midwives always use conventional partographs to monitor the labor progress meanwhile web-based partograph is a new techonolgy to them. Pusparinda (2015) found that the ability of midwives in using conventional partographs was $74.2 \%$. The percentage of their ability in using conventional partograph, which is considered in high level, is very influential in filling partographs. This is in line with research conducted by Enginda Yisma et al. (2013) who stated that partograph training affected in increasing knowledge with a $P$ value $<0.05$. Rahmi (2016) added that there were a relationship between attitude, and the knowledge of completeness in recording conventional partographs.

The result of Mann-Whitney Test shows that the timeliness of monitoring using web-based partograph was better than the use of conventional partographs. It is proved by the results of $p$ value at $0.000(<0.05)$ and the results of monitoring the emergency deliveries with $p$ value is at $0.014(<0.05)$. These results show that there was a difference between monitoring using web-based partograph and conventional partograph. There were 30 respondents who were monitored by using web-based partograph and 5 out of 30 respondents were in emergencies when being monitored by web-based partograph. The emergencies cases involved 1 mother in labor who faced fetal distress, 2 of them faced prolonged labor in the first phase of labor, and 2 of them faced placental retention in the third phase of labor. Web-based partograph was used because the system has time notification as a reminder which helps the midwives to monitor the patients based on the particular time. This is in line with a study conducted by Heather et al., (2013) who found that web-based partograph can help health workers in monitoring the labor progress. In addition, Yulianti N.T et al., (2017) found that the use of computer-based partograph can 
assist midwives in monitoring the labor progress and it only takes 8.6 hours to fill the partographs completely.

The result of P-value of referral process in this study is $1,000(>0.05)$. It means that there was no difference in monitoring using web-based partograph and conventional partograph because all patients who faces emergency were not referred. It was revealed by the midwife that the referral system at the community health center is very difficult to do because it takes time to send data before the patient is referred. The use of partographs in monitoring labor is very important because it can help midwives in determining the referrals if there is an emergency (Ultingtyas, 2009). Partographs can make a referral process in 4 hours after labor monitoring passes the alert line as it is stated in the regulation of the Minister of Health of the Republic of Indonesia number 28 of 2017 Article 19 Paragraph 2 that health treatment to mothers in letter (b) normal delivery assistance and in letters (d) handling emergencies, followed by referral.

\section{Conclusion}

The use of web-based partographs on monitoring the progress of labor helps midwives in detecting early emergencies. Therefore, it helps midwives in decision making.

\section{Acknowledgments}

The authors would like to express their special thanks to the leaders of community health center in Antang and Bara- Baraya, the midwives, the maternity for their support and assistance during the study.

\section{Competing Interests Statement}

The authors declare that there are no competing or potential conflicts of interest.

\section{References}

Archa, M. V., \& Prem, S. (2013). Effectivennes of individual teaching on knowledge regarding partograph among staff nurses working in maternity wards of selected hospitals at mangalore. International Journal of Recent Scientific Research, 4

Asibong, U., Okokon, I. B., Agan, T. U., Oku, A., Opiah, M., Essien E. J., \& Monjok, E. (2014). the use of the partograph in monitoring labor: A cross-sectional study among obstetric caregivers in General Hospital, Calabar, Cross River State, Nigeria. Int J Womens Health, 6, 873-80. https://doi.org/10.2147/IJWH.S49188

Assarag, B., Dujardin, B., Delamou, A., Still, F. Z., \& De Brouwere, V. (2015). Determinants of maternal near-miss in Morocco: too late, too far, too sloppy?. PLoS One, 10(1), $\mathrm{e} 0116675$. https://doi.org/10.1371/journal.pone.0116675

Bedwell, C., Levin, K., Pett, C., \& Lavender, D. T. (2017). A realist review of the partograph: when and how does it work for monitoring labor? BMC Pregnancy Childbirth, 17(1), 31. https://doi.org/10.1186/s12884-016-1213-4

Chaturvedi, S., Upadhyay, S., De Costa, A., \& Raven, J. (2015). Implementation of the partograph in India's JSY cash transfer program for facility births: a mixed methods study in Madhya Pradesh province. BMJ Open, 5(4), e006211. https://doi.org/10.1136/bmjopen-2014-006211

Cunningham, A. F. (2017). Williams Obstetrics. Jakarta; EGC.

Dalal, A. R., \& Purandare, A. C. (2018). The Partograph in Childbirth: An Absolute Essentiality or a Mere Exercise?. J Obstet Gynaecol India, 68(1), 3-14. https://doi.org/10.1007/s13224-017-1051-y

De Plecker, E., Zachariah, R., Kumar, A. M., Trelles, M., Caluwaerts, S., Van Den Boogaard, W., ... \& Van den Bergh, R. (2017). Emergency obstetric care in a rural district of Burundi: What are the surgical needs?. PLoS One, 12(2), e0170882. https://doi.org/10.1371/journal.pone.0170882

Florence, G.-L., Beverley, A., Gyekye, F. O., \& Schopflocher, D. (2013). The Relationship Between The Use Of The Partograph and Birth Outcomes At Korle-Bu Teaching Hospital. Elsevier, 461-467. https://doi.org/10.1016/j.midw.2012.03.002

Konlan, K. D., Kombat, J. M., Wuffele, M. G., \& Aarah-Bapuah, M. (2016). Knowledge and attitudes of Midwives on the use of the partogram: a study among Midwives in the Tamale Metropolis. Matern Health Neonatol Perinato, l, 2. https://doi.org/10.1186/s40748-016-0030-0

Kumar, A., \& Agrawal, N. (2016). Brought in Dead: An Avoidable Delay in Maternal Deaths. J Obstet Gynaecol India, 66(Suppl 1), 60-6. https://doi.org/10.1007/s13224-015-0762-1

Kuppens, B. C., Smailbegovic, I., Houterman, S., De Leeuw, I., \& Hasaart, T. H. (2017). Fetal heart rate 
abnormalities during and after external cephalic version: Which fetuses are at risk and how are they delivered?. BMC Pregnancy Childbirth, 17(1), 363. https://doi.org/10.1186/s12884-017-1547-6

Mandiwa, C., \& Zamawe, C. (2017). Documentation of the partograph in assessing the progress of labor by health care providers in Malawi's South-West zone. Reprod Health, 14(1), 134. https://doi.org/10.1186/s12978-017-0401-7

Markos, D., \& Bogale, D. (2016). Knowledge and utilization of partograph among health care professionals in public health institutions of Bale zone, Southeast Ethiopia. Public Health, 137, 162-8. https://doi.org/10.1016/j.puhe.2016.02.026

Mathibe Neke, L. F., \& Matupa, B. (2013). The partograph: A labor management tool or a Midwifery record?. International Journal of Nursing and Midwifery, 5(8), 145-153. https://doi.org/10.5897/IJNM2013.0115

Mezmur, H., Semahegn, A., \& Tegegne, B. S. (2017). Health professional's knowledge and use of the partograph in public health institutions in eastern Ethiopia: a cross-sectional study. BMC Pregnancy Childbirth, 17(1), 291 (291). https://doi.org/10.1186/s12884-017-1477-3

Muhammad, S. K. (2012). Aplikasi Partograf Sebagai Media Bantu Dalam Proses Persalinan di Rumah Sakit Ibu dan Anak Arvita Bunda Yogyakarta. DASI, 13(2).

Nakimuli, A., Nakubulwa, S., Kakaire, O., Osinde, M. O., Mbalinda, S. N., Nabirye, R. C., ... \& Kaye, D. K. (2016). Maternal near misses from two referral hospitals in Uganda: A prospective cohort study on incidence, determinants and prognostic factors. BMC Pregnancy Childbirth, 16, 24. https://doi.org/10.1186/s12884-016-0811-5

Ollerhead, E., \& Osrin, D. (2014). Barriers to Achieving partograph and incentives for use in obstetric practice in low- and middle-income countries: a systematic review. BMC Pregnancy Childbirth, 14, 281. https://doi.org/10.1186/1471-2393-14-281

Pusparinda D, L. A. (2015). The Use of Partogram in Cesarean Section. 11 No. 1.

Trisna, Y. N., Syarif, S., Ahmad, M., Manyu, B., \& Isharya, S. (2018). Comparasion partograph based on computer systems and partograph conventional record monitoring report on the progress of labor. Chem Tech research, 11. https://doi.org/10.20902/IJCTR.2018.110540

Wakgari, N., Tessema, G. A., \& Amano, A. (2015). Knowledge of partograph and its associated factors among obstetric care providers in North Shoa Zone, Central Ethiopia: a cross sectional study. BMC Res Notes. https://doi.org/10.1186/s13104-015-1363-x

Wang, L., Kuromaki, K., Ochi, A., Kikugawa, A., Matsunaga, S., \& Takagi, A. (2016). Nuchal cord complication in male small for gestational age increases the risk of fetal distress during labor. Taiwan J Obstet Gynecol, 55, 568-74. https://doi.org/10.1016/j.tjog.2016.03.002

Widyana, E. D. (2011). Evaluasi Pelaksanaan Rujukan Ibu Bersalin Dengan Komplikasi Persalinan Oleh Bidan Desa Di Puskesmas Sukorejo Wilayah Dinas Kesehatan Kabupaten Pasuruan. Penelitian Kesehatan Suara Forikes, 2(4).

Yisma, E., Dessalegn, B., Astatkie, A. \& Fesseha, N. (2013a). Completion of the modified World Health Organization (WHO) partograph during labor in public health institutions of Addis Ababa, Ethiopia. Reprod Health, 10(23). https://doi.org/10.1186/1742-4755-10-23

Yisma, E., Dessalegn, B., Astatkie, A., \& Fesseha, N. (2013b). Knowledge and utilization of partograph among obstetric care givers in public health institutions of Addis Ababa, Ethiopia. BMC Pregnancy Childbirth, 13(17). https://doi.org/10.1186/1471-2393-13-17

Yuhandari, \& Winiarti, R. (2014). Pembuatan sistem pakar berbasis web untuk mendiagnosa penyakit anak. Kom Tek Info, 1(2).

Yusuf, R. N. (2016). Faktor-faktor yang berhubungan dengan pengisian partograf secara lengkap oleh bidan praktek mandiri di wilayah kerja puskesmas lubuk buaya padang. Saintika Medika Journal, 7(1).

\section{Copyrights}

Copyright for this article is retained by the author(s), with first publication rights granted to the journal.

This is an open-access article distributed under the terms and conditions of the Creative Commons Attribution license (http://creativecommons.org/licenses/by/4.0/). 